\title{
Intra-Cultural Variation, Zone of Acceptance and Managerial Discretion: A Theoretical Discussion
}

\author{
Moustafa Salman Haj Youssef ${ }^{1} \&$ Ioannis P. Christodoulou $^{1,2}$ \\ ${ }^{1}$ Westminster Business School, University of Westminster, 35 Marylebone Road, NW1 5LS, London, United \\ Kingdom. \\ Correspondence: Moustafa Salman Haj Youssef, Westminster Business School, University of Westminster, 35 \\ Marylebone Road, NW1 5LS, London, United Kingdom. \\ Received: January 22, 2017 \\ Accepted: February 1, 2017 \\ Online Published: February 3, 2017 \\ doi:10.5430/bmr.v6n1p42 \\ URL: http://dx.doi.org/10.5430/bmr.v6n1p42
}

\begin{abstract}
This paper examines the theoretical relationship between intra-cultural variation and managerial discretion. Research into the degree of discretion, or latitude of actions, has primarily focused on the individual-, organizational-, and industry-level factors, which either allow or constrain executives to take strategic actions. Despite, the recent attempt to discover the impact of national culture, mainly values, on managerial discretion, culture has been studied on an aggregate level by assuming spatial homogeneity within a country. However, recent evidences have shown that intra-cultural variation could be as salient as or sometimes even more than inter-country variation, yet there has been no discussion on its potential association with managerial discretion. As such, we address this gap and investigate the relationship of this cultural aspect with managerial discretion. Using institutional, stakeholder and upper echelons theories, our study proposes a strong relationship between intra-cultural variation and managerial discretion. Therefore, our study contributes to the strategic management and culture literature by providing a more nuanced understanding of such relationship and most importantly by introducing a new national construct that could play an important role in the strategic decision making of business executives.
\end{abstract}

Keywords: Intra-cultural variation, Cultural heterogeneity, Managerial discretion, National-culture, Zone of acceptance

\section{Introduction}

The management field in general focuses solely on the one aspect of national culture, particularly values, while neglecting other important aspects (e.g. intra-cultural variation) (Aktas et al., 2016). Such orientation has led to a shortcoming in our understanding of various management constructs, including managerial discretion, and this has led top scholars to call for an expansion of the "conceptual toolkit" to broaden the scope of cross-cultural and management research (Gelfand et al., 2006). Recent research in the discretion literature have unveiled important cultural influences on managerial discretion, notably individualism, uncertainty tolerance and power distance. However, beyond the need to uncover the values aspect of culture, there should be more focus on the importance of considering the implications of the varying degrees of behavior within a given culture. Intra-cultural variation is an important, yet under-researched, dimension of national culture that should attract our attention, especially in terms of its association with executives' latitude of actions.

Intra-cultural variation reflects the degree of homogeneity/heterogeneity in views innate to a society (Carpenter, 2000; Uz, 2015). It is reasonable to investigate cultural dimensions from an aggregate level by assuming greater homogeneity within a country, however, drawing upon the idea that culture is multi-dimensional, there should be a balance between cross-national and intra-national diversity in culture (Tung, 2008). Although some initial attempts have highlighted the importance of within cultural differences (intra-cultural variation) in affecting several micro and macro-level variables (e.g. Beugelsdijk et al., 2014). Yet, its association with managerial discretion has not been explored. Such shortcoming would limit our understanding of the national factors that could drive or hinder the freedom in decision making particularly for executives residing in each country.

Accordingly, our paper seeks to theoretically discuss the potential implication of intra-cultural variation on managerial discretion. This is achieved by integrating the advancement in cross-cultural research with the strategic management realm. Based on the original conceptualization of managerial discretion (Hambrick and Finkelstein, 
1987), the effect of various stakeholders' groups and their zones of acceptance on managerial discretion seems not to have been the subject of previous scholarly attention. Our work draws upon the stakeholder theory (Donaldson and Preston, 1995) to conceptually explain that the latitude of executive actions is not solely related to the aggregate acceptance of most stakeholders but is also subject to the acceptance of individual stakeholders. Therefore, we highlight the importance of intra-cultural variation, provide a deeper understanding of this construct, and introduce new national-level antecedents of managerial discretion.

\section{The Concept of Managerial Discretion}

Managerial discretion is conceptualized as the latitude in executives' decision-making (Hambrick and Finkelstein, 1987). It explicitly emerges as a conceptual link between theories that are predominantly deterministic ((e.g. population ecology (Hannan and Freeman, 1977), or neoinstitutionalism (DiMaggio and Powell, 1983)) and those that are mostly managerial (e.g. upper echelons (Hambrick and Mason, 1984)). Discretion exists to the extent that constraints to decision-making are relatively absent and when multiple plausible alternatives are available for executives to choose from. As such, it is a function of the individual executive (e.g. locus of control), the organization (e.g. resource availability) and the task environment (e.g. industry regulations) characteristics or any combination of these. Together, these internal and external factors comprise a powerful range of possible limitations or catalysts for executive actions. Managerial discretion is generally enforced through managerial sources of power including but not limited to coercive, referent, legitimate, expert, and reward power (Riasi and Asadzadeh, 2016). According to Uhl-Bien and Carsten (2007), managerial power can be defined as the sense of control and the perception that one has the ability to influence outcomes.

At the individual level, research shows that executives operating within the same domain can foresee a distinct set of actions depending on their individualities and psychological characteristics (Wangrow et al., 2015). Some can envision a wider range of alternatives and create multiple courses of actions that would affect organization outcomes. These psychological micro-foundations are unique features that determine executives' discretion. For instance, executives with greater locus of control (Carpenter and Golden, 1997), ambiguity tolerance (Dollinger et al., 1997), networking relations (Geletkanycz and Hambrick, 1997), risk-taking behavior (Roth, 1992) and lower commitment to the status quo (McClelland et al., 2010) possess more discretion.

At the organizational level, firms with abundant resources that are easily transferable allow executives to foresee change and choose from a wider variety of alternatives (Hambrick and Finkelstein, 1987). Similarly, the lack of ingrained culture and the existence of a passive board accord executives with more discretion (Boyd and Salamin, 2001). Relatedly, CEO duality increases the likelihood of strategic change, which in turn enhances managerial discretion (e.g. Quigley and Hambrick, 2012; Kim, 2013). In contrast, organizations with an entrenched, rigid culture resulting from standardised routines and control place strict constraints on executives' actions and make it difficult for them to initiate any strategic change (e.g. Key, 2002; Wangrow et al., 2015).

Also, the task environment, in which firms operate, could drastically alter executive actions. Some industries can afford a greater variety of choices/actions than others. Hambrick and Abrahamson (1995) argue that advertising and R\&D intensity along with market growth have a positive impact on managerial discretion. However, industry regulation constrains executives' latitude of actions (Peteraf and Reed, 2007). Similarly, Finkelstein (2009) finds demand variability along with industry concentration to negatively affect CEO discretion.

Although Hambrick and Finkelstein (1987: 379) argue that discretion is closely related to "the degree to which the environment allows variety and change", most of the previous research, conceptualizes the task environment in terms of industry characteristics. Very little work has considered the impact of the macro-environment, more precisely the national setting, on executive discretion. Only recently, managerial discretion has been examined on a national-level (Crossland and Hambrick, 2011). However, the examination was limited as it solely refers to the aggregate conceptualization of culture (cross-country differences) and assume greater homogeneity within countries.

\section{The Concept of Intra-Cultural Variations}

To many scholars, the variations between members of a society/country are commonly referred to as cultural differences (Hofstede, 1991). However, members of a culture ought not to be like each other, where in some cultural environments, there exists a degree of homogeneity/heterogeneity (variation) in behavior innate to that society (Carpenter, 2000; Uz, 2015). Most research focuses on the 'central tendency' of societal members, which denotes the typical members of a country. Quantitatively, the central tendency of societal members on a specific characteristic is mainly represented by the cultural means of such attributes (Au, 1999). The essence of cross-cultural research is to offer scientific interpretation of cultural differences rather than simply presenting the differences between countries 
(e.g. Mullen, 1995). Not considering within-country variance or diversity may well lead to missing an opportunity for a more nuanced, holistic and comprehensive approach to studying national culture. As such, intra-cultural variation, which has been ignored by cross-cultural researchers, is an important construct to further understand cultural implications.

Au (1997, 1999, 2000; Au and Cheung, 2004) is among the main allies of the intra-cultural variation construct and perhaps the only scholar who makes the most explicit and strongest argument for the integration of the intra-cultural variation construct in cross-cultural studies. He argues that several factors could play an important role in determining intra-cultural variation. Amid these factors are individual demographics, moral discipline, government and organization policy along with other variables (e.g. ethno-linguistic (Puia and Ofori-Dankwa, 2013)). However, $\mathrm{Au}$ (1999) emphasised that societal members' behavior triggered by their cultural values and practices within a given country may well be regarded as the prominent antecedent of intra-cultural variation.

This is particularly important in the context of managerial discretion as it helps to define the boundaries of executive actions. In other words, it may be perceived that a CEO operating in a homogenous culture would be faced with established practices, limiting any attempt to deviate from the 'central tendency' of the society. In such cases, the array of actions would be narrow. On the other hand, a CEO in a heterogeneous society would have a wider array of actions to choose from, as the boundaries of the central tendencies are wider. However, this is not necessarily the case as will be seen in the below discussion. In our discussion, we relax the homogeneity assumption of national culture, and like other scholars (e.g. Venaik and Midgley, 2015), we believe that there would be significant heterogeneity within and across countries, which will play a role in changing the degree of discretion an executive can have.

Before developing this line of reasoning, it is important to highlight the current discussion on intra-cultural variation and put the concept into its proper context, which is present in the next section. Following that, we describe the theoretical building blocks for the proposed relationship between intra-cultural variation and managerial discretion.

\section{Intra-Cultural Variation Review}

Culture is an important concept to many scholars in a wide range of disciplines. Influenced by the work of Hofstede $(1980,2001)$ and more recently House et al. (2004), the scholarly community, particularly the cross-cultural business party, has constantly represented culture based on national scores. Notwithstanding the acceptance and importance of these national scores, studies have been criticised from various angles, such as construct validity (e.g. Brewer and Venaik, 2014), ideological basis (e.g. Ailon, 2008), and homogeneity assumption (e.g. Dheer et al., 2015). Particularly relevant is the latter assumption that most earlier works have taken for granted. As argued by some academics, such a supposition may be acceptable if the cross-cultural variance is greater than the within-country variance (Hanges and Dickson, 2006; Ronen and Shenkar, 2013), which is not always the case in cross-cultural research (Venaik and Midgley, 2015).

Recent discussion in the cross-cultural and international management literatures showed the importance and appropriateness of within-country variance (intra-cultural variation) to uncover various cultural implications (e.g. Au and Cheung, 2004; Peterson et al., 2012; Tung and Verbeke, 2010). A typology presented by Klein and Kozlowski (2000) argue that the conceptualisation of a group has three main properties: global, shared and configurational. The global aspect relates to the encompassing properties that are mostly dominant and recognisable, such as political system, economic growth, etc. Although the shared and configurational properties both emerge from the characteristics of a group (in this case a country), the shared properties are common amongst all the group members that embrace such a particularity. By contrast, the configurational property is not shared and is unique to each group member (Ralston et al., 2014). These differences are mainly due to either meso-level (e.g. religion, region) or individual-level attributes (e.g. age or gender). While most of the works in the cross-cultural literature have relied on the first two properties of Klein and Kozlowski's (2000) typology, some have incorporated the within-country differences to provide a better understanding of the impact of culture. Recently, Venaik and Midgley (2015) incorporated the configurational perspective and reconciled it with the national averages theoretical construct to develop cultural archetypes. Similarly, Richter et al. (2016) argue that the configurational perspective allows for a more holistic understanding of cultural dimensions and their consequent effects.

Moreover, Tsui et al. (2007) argue that culture scholars rely heavily on the consideration of the global and shared properties of national culture and assume that shared property, using mean scores, is the main characteristic of a nation. Similarly, the observations of Au and Cheung (2004) explicitly indicate the lack of consideration of the dispersion of behavior or practices within a country. In their review of cross-cultural studies, Kirkman et al. (2006) pointed to this gap and encouraged researchers to employ the intra-country variation construct. Such importance is 
also reflected in Kirkman et al.'s (2009) study of Chinese and US employee-manager relations, in which they concluded that to understand culture, one needs to know the within-country variance and not only the shared attributes of a society. In the same vein, Steel and Taras (2011) described in their meta-analysis study that almost $90 \%$ of variance in cultural attributes can be found within countries. Therefore, the adoption of the configurational perspective, which has been recognised by some scholars (e.g. Fischer et al., 2011; Gurven et al., 2008; Lenartowicz and Roth, 2001), is crucial to provide new insights and develop the cross-cultural field.

The idea of intra-cultural variation can be dated back to early research on ecological fallacy, which states that individuals in a group do not necessarily possess the average attribute(s) of that group (Robinson, 1950). Such an argument has been also present in anthropological studies, such as Pelto (1975) who offers a thorough discussion on the factors that have made the homogeneity assumption so popular and attractive and the implications that intra-cultural variation has on the advancement of such theory. Early works (e.g. Au, 1999; Chan et al., 1996; Schwartz and Sagie, 2000) show that intra-cultural variation exhibits inconsistent correlations with cultural means and provide differing findings. Au and Cheung (2004) empirically demonstrated that intra-cultural variation and cultural mean are not substitutes, which provides supporting argument for the importance of studying the implications of both constructs. The fundamental importance of intra-cultural variation is to show the extent to which the shared practices within a society are widely and deeply shared amongst its members (Puia and Ofori-Dankwa, 2013). Drawing on the multi-layered construct of culture (Leung et al., 2005), Tung (2008a) argued for the necessity to account for intra-national variation when conducting cross-cultural research. Despite these calls, studies have continued to adopt the global and shared perspective when conducting cross-cultural research (Ralston et al., 2014), which has led to fallacious assumptions of cultural homogeneity within a country (Tung and Verbeke, 2010). The answer for this could be multi-faced, in part due to methodological issues (i.e. the unavailability of published large-scale data on within-country variation) (Fischer, 2006) and in part to a lack of appreciation of the contribution that such a construct could bring to our understanding (e.g. Buchholz et al., 2009).

As previously stated, to the extent to which cross-cultural variation is greater than within-country variation, the use of national scores would be justifiable (Hanges and Dickson, 2006). This represents the main argument of the proponents of the national culture perspective who believe that individual norms (i.e. behavior, values, beliefs, etc.) constitute the dominant thrust of shared enculturation (Schwartz, 1999: 26). While acknowledging this fact, the homogeneity of a given culture (country) is not universal and some researchers have already shown that. In the field of international marketing, appreciation of intra-country variation or heterogeneity in attitudes, practices and even values are considered essential for various marketing strategies, such as customer segmentation and positioning (e.g. Broderick et al., 2007; Ter Hofstede et al., 2002; Wedel et al., 1998). In other disciplines, intra-cultural variation has been shown to influence organizational and social outcomes, particularly Au and Cheung (2004), who empirically illustrate that intra-cultural variation has a negative effect on job and life satisfaction as opposed to the cultural mean. $\mathrm{Au}$ and Cheung (2004) were not the only scholars that investigated the role of within-country variation and work-related issues; likewise, Hoorn (2015) discovered that intra-cultural variation explains, by far, the difference in work values within a country. Also, the salient effect of within-country variance has been uncovered by Tung and Baumann (2009), who compared individuals' behavior towards material possession and savings among a sample of countries (e.g. Canada, Australia, China). Their findings strongly suggest that there were more similarities across countries than within countries based on the individual background of a group. Others established a strong link between intra-country variation and technological innovations. Puia and Ofori-Dankwa (2013) employed the within-country diversity framework to explore the relationship between cultural diversity (within a given country) and national innovativeness. Their findings suggest that intra-cultural variation is independently and positively related to national innovativeness. Within business ethics, Ralston et al. (2014) tested the utility of intra-cultural variation on two cultural dimensions (individualism and collectivism) to predict the ethical behavior of managers. In their study of 48 societies, they found that variation within countries make a more suggestive contribution to explain the perception of ethical behavior. Another example of the use of intra-cultural variation in international business and cross-cultural studies is Beugelsdijk et al.'s (2014) work on foreign affiliates' sales. The study's findings suggest that the overestimation of foreign affiliates' sales is significantly and positively related to the intra-cultural variations of the host country.

With the progression of cross-cultural research, scholars have further developed a somewhat old construct to gauge the extent of the clarity and pervasiveness of norms in each country and how much tolerance exists there for deviant behavior (Gelfand et al, 2006). Cultural tightness and looseness is a related construct to intra-cultural variation based on within-country variance. In loose cultures, norms are expressed within a broad range of alternative means and there exists a lack of regularity, discipline and regimentation. Such cultures tend to tolerate divergent practices. In 
contrast, cultures that are tight have established strong and clear norms by developing order and sanctioning systems for governing deviant behavior.

Given these characteristics, it is expected that intra-cultural variation in tight cultures is smaller than in loose societies. As previously discussed, cultural tightness-looseness has its roots in various academic disciplines, including sociology (e.g. Boldt, 1978b), anthropology (Pelto, 1968), psychology (Berry, 1966) and of course international business and cross-cultural research (Gelfand et al., 2011). Research has discovered that national contexts of tightness and looseness vary widely between countries and that such a construct is distinct from the actual cultural dimensions (Aktas et al., 2016; Gelfand et al., 2011). This construct has been linked to several organizational, managerial and national outcomes (Taras et al., 2010), such as negotiation (Gunia et al., 2011), stock-price synchronicity (Eun et al., 2015), job satisfaction for expatriate manpower (Peltokorpi and Froese, 2014), organizational creativity (Chua et al., 2015) and even terrorism (Gelfand et al., 2013). Recently, cultural-tightness and looseness have been linked to managerial discretion (Crossland and Hambrick, 2011). However, cultural tightness-looseness and intra-cultural variation are not the same construct, both may well be related to each other particularly in the sense of greater variety of behavior but differ in quantitative and theoretical terms.

From a theoretical perspective, cultural tightness-looseness has two main dimensions; the first relates to the strength and clarity of social norms - in other words the pervasiveness of these norms within a given society; and the second relates to the strength of sanctioning, which means the degree of tolerance that a society has towards deviant behavior (Gelfand et al., 2006). Whereas, intra-cultural variation refers to the actual distribution of behavior of the population in given culture ( $\mathrm{Au}, 1999)$. Its key component is the heterogeneity in a society's practices and values (Venaik and Midgley, 2015) and the extent to which societal members do not follow the central tendency of the society (variance of attributes) (Au, 1999). Also, the antecedents of intra-cultural variation mainly lie within the actual members of the society as opposed to cultural tightness-looseness, where the proxies are mainly related to exogenous factors. From a quantitative standpoint, the operationalisation of these constructs is completely different. Intra-cultural variation is mainly operationalised using the standard deviation of behaviors ( $\mathrm{Au}, 1999$; $\mathrm{Au}$ and Cheung, 2004) or using proxy measures such as ethno-linguistic diversity (Beugelsdijk et al., 2014). On the other hand, cultural tightness is measured through a set of variables that relates to historical, ecological and societal factors. The main measure developed by Gelfand et al. (2011) considers ecological and historical threats, socio-political institutions, legal system, etc. Even recent operationalisation techniques (Uz, 2015) have incorporated socio-political, threat to survival, psychological and behavioral-inhibition factors. The distinction between these two constructs has been illustrated by extant research. For instance, the Netherlands, a relatively loose culture (Gelfand et al., 2011), has small variation, whereas, India, which scored very high on Gelfand et al.'s (2011) scale, is characterised as having high intra-cultural variation ( $\mathrm{Au}, 1999)$.

\section{Theoretical Discussion: Intra-cultural Variation and Managerial Discretion}

Crossland and Hambrick (2011) found that cultural looseness is positively related to managerial discretion. This is because in loose societies, standards of behavior are more ambiguous, which leads to less restrictiveness, whereas tight cultures provide clear expectations on how entities (including executives) should behave in that culture. If intra-cultural variation is like tightness-looseness, which is not the case, as discussed earlier, then we may expect it to have a positive relationship with managerial discretion. In contrast, we speculate that intra-cultural variation would negatively affect managerial discretion. The logic can be linked to various management and non-management theories. Starting with the latter, in the discipline of international marketing, studies find that intra-cultural heterogeneity is an important construct for marketing managers as they need to understand the behavior, attitudes and values of a distinct set of customer segments, which is indeed important for positioning purposes (Broderick $e t$ al., 2007). When managers are faced with such a diverse set of customer groups, decisions become tougher and little latitude exists in their decision making. The same argument is echoed in the management literature, particularly the upper echelons theory. Executives have restricted information-processing abilities and must be selective in where they focus their attention (Abrahamson and Hambrick, 1997). Because discretion confers options and the diversity associated with the selection of these options (Nelson, 1991), the greater the uncertainty in each environment (in this case society), the more executives will consider a wider variety of means to diverse ends (Abrahamson and Hambrick, 1997). Countries that scored high on uncertainty avoidance have been characterised as being low on intra-cultural variation (Au, 1999). This means that the array of options available to executives in these environments is less diverse, implying low managerial discretion.

Furthermore, existing work in the stakeholder realm argues the importance of treating various stakeholder groups well, as it contributes to organizational performance (e.g. Donaldson and Peterson, 1995; Harrison et al., 2010), 
which is the focal objective of executives. Stakeholders are categorised into two main types: self-regarding, who only care about themselves (Fehr and Falk, 2002); and reciprocal, who care about others and try to punish unfair treatment even if that punishment is costly (Engelmann and Strobel, 2004). Philips et al. (2011) argue that executives, and by extension their firms, have the latitude to choose predefined actions in response to existing internal or external events. However, it is well documented in the discretion literature that this latitude is limited and subject to various internal (e.g. firm characteristics, executive individualities) (Wangrow et al., 2015) and external (e.g. industry and country characteristics) (Crossland and Hambrick, 2007) factors. Proponents of stakeholder research have emphasised the important role of external factors in influencing executives' behavior. The argument lies in the premises that firms function within a collection of constituencies that have a varying degree of power (Mitchell et al., 1997), which ultimately leads to constraints on executives' actions. Thus, it would be almost impossible to explain the viability of stakeholder influence as an external factor affecting firms' outcomes without acknowledging the condition of this influence, which is the degree of managerial discretion. If executives are not accorded enough discretion, then it is unreasonable to hold them accountable for mistreating stakeholders.

Research shows that the heterogeneity of stakeholders is well observed across cultures and even within an environment (country or industry) (e.g. Gardberg and Fombrun, 2006). These stakeholder groups impose strong normative and coercive pressures on organizations (Delmas and Toffel, 2004), which consequently lead to pressures on executives' actions (institutional argument based on Di Maggio and Powell, 1983). Top managers are exposed to and face a population of distinct stakeholder groups, each with different motives and heterogeneous behavior (Bridoux and Stoelhorst, 2014). In their own words, Hambrick and Finkelstein (1987: 374) state that: "To us, constraint exists whenever an action lies outside the 'zone of acceptance' of powerful parties who hold a stake in the organization... Extending the concept to other types of stakeholders, one can think of board members, bankers, regulators, employees, customers as well as other parties, as all having their own zones of acceptance". Hence, actions that are acceptable by a given stakeholder group may well be objectionable to others. In such an instance, executives exposed to a diverse set of stakeholder groups are strongly challenged to take actions that are in line with the acceptance scale of these stakeholders. Bear in mind that discretion exists to the extent to which actions fall within the zone of acceptance of stakeholders (Crossland and Hambrick, 2011). In this case, there will be more than one zone of acceptance, with each related to a stakeholder group, because of the development of cultural archetypes due to greater heterogeneity (Venaik and Midgley, 2015). Stakeholder theory distinguishes between the various stakeholders a manager is exposed to and recognises that interests differ both between and across these stakeholder groups (Wolfe and Putler, 2002). Executives' discretion in this case is a function of both the holder-specific discretion, particularly to each stakeholder group, and the aggregate discretion, which is common across all stakeholder groups. In the cultural realm, managerial discretion was considered from the latter dimension - the aggregation of stakeholders' zones of acceptance using cultural values (Crossland and Hambrick, 2011). However, the particularity of each stakeholder group's zone of acceptance is of great importance. This is because increasing the heterogeneity within a given context would lead to the creation of several cultural archetypes, which in turn increases the institutional constraints that are imposed on executives operating in such a context. Any actions that do not conform with the zone/s of acceptance of most stakeholder groups would be perceived as objectionable and as such will lead to cultural misfit, illegitimacy and inefficiency (Roth et al., 2011). Therefore, the latitude of available options or actions would be limited.

In contrast, in societies with low intra-cultural variation, executives need to adapt to few stakeholder groups, which allows them to foresee a broader set of actions. It is easier for individuals to attend to a homogenous culture as opposed to a heterogeneous one (Au, 1999), because the contact with a divergent set of exemplars may become confusing, and thus provide further constraints on the information-processing ability of executives (Abrahamson and Hambrick, 1997). Cognitive theorists argue that executives encounter more information than their cognitive capability can integrate (Surroca et al., 2016); for that reason, they focus (pay attention to) on domains that they perceive as being critical. This attention pattern will therefore determine their strategic agenda (Nadkarni and Barr, 2008). In the absence of the pressure generated from a variety of stakeholder groups, executives would not be tended to adhere to a diverse set of societal expectations (Campbell, 2007). It becomes easier for an executive in this situation to make greater strides to interpret and comprehend a smaller set of information, which will ultimately be reflected in more strategic change (Cho and Hambrick, 2006) and the generation of new choices (Cohen and Levinthal, 1990). Consequently, the latitude of actions increases. An executive focusing on one stakeholder group may well be in a position of high discretion vis-à-vis that individual group, but at the cost of added constraints from other stakeholder groups. In societies with a limited number of stakeholder groups (low intra-cultural variation), the opportunity cost to attend to the powerful stakeholder groups decreases and executives can attend to the needs of a 
concentrated set of individual stakeholder groups, which ultimately generates higher discretion. Accordingly, and based on the above discussion, we propose that greater intra-cultural variation reduces the degree of managerial discretion.

\section{Conclusion \& Research Implications}

Our theoretical discussion of the construct of intra-cultural variation and its potential implications on executives' latitude of actions opens a new horizon in the literature and adds an important antecedent to the discretion construct. The stream of research in the national-level dimension of managerial discretion often uniformly ignores the heterogeneity that exists in a country. By highlighting the potential implication of the intra-cultural variation, we contribute to strategic management literature by extending our understanding of the national-level antecedents of managerial discretion. Also, for several decades, stakeholder theory has mainly rested on the side of the voluntaristic perspective, which argues that managerial decision and behavior are the variables that shape the relationship between firms and stakeholders (Phillips et al., 2010). Such perspective implicitly assumes that managers have enough latitude of actions to attend to stakeholders' needs. However, this is not always the case as the degree of managerial discretion is a function of the internal and external constraints facing managers. We argued that while discretion is a vital intervening variable on its own right, it also has a powerful role in explaining stakeholder-firm relationships. Therefore, we conceptually tried to fill in the gap that is currently present in the stakeholder theory by including the concept of managerial discretion as an important construct to take into consideration when talking about stakeholder management.

Our theoretical discussion provides important managerial implications, for instance our proposition could shed light on the stakeholder orientation of firms. Stakeholder orientation refers to managers' behavior towards stakeholders, which considers the totality of firms' approach to managing stakeholders. According to Phillips et al., (2011), stakeholder management is categorised in two types: narrow and broad orientation. At one extreme, managers could hold a narrow orientation by constantly honouring and focusing on the interests of a given stakeholder group over the interests of other stakeholder groups. At the other extreme, managers could exhibit broad orientation in which they focus on a wide range of stakeholder groups. If, as proposed in this paper, greater intra-cultural heterogeneity reduces managerial discretion, then we may well expect that this would result in executives following a broader stakeholder orientation. When a CEO is faced with greater constraints from several stakeholder groups, he/she will not be able to take actions that favor one group over the other and would focus on attending to the needs of all stakeholder groups to reduce those constraints. In such scenario, the CEO is expected to put more effort into serving a wider set of stakeholders (e.g. community, employees, customers, etc.) and ignoring any initiatives that do not benefit all of them. Whereas, having a smaller number of stakeholder groups would accord executives more discretion which in turn enable them to categorise stakeholders and attend to the need of the most powerful and important group at the expense of others, which will ultimately lead to adopting a narrow stakeholder orientation.

Furthermore, our proposition could have implications on leadership effectiveness. Recent endeavours in the leadership literature have made interesting theoretical conceptualisation by illuminating what can be considered as emic (culture specific) or etic (universal) in terms of leadership attributes and effectiveness (e.g. House et al., 2014). Such research stream has shown that leadership is culturally dependent and that perception of effective leadership is not only dependent on the central tendencies of a given culture but also on its tightness-looseness dimension (e.g. Aktas et al., 2016). Similarly, we expect that intra-cultural variation along with managerial discretion to be closely related to the perception of effective leadership. For instance, in heterogeneous cultures, executives are faced with a greater number of stakeholder groups and as such are accorded low discretion, their attention would be directed to all or majority of stakeholder groups. In such situation, it is expletive that participative leaders would be perceived as an effective leadership style because it reflects the degree to which executives take into consideration the need of others and involve important stakeholders in the decision-making processes. On the other hand, in homogenous cultures, in which executives enjoy more latitude of action, the autonomous leadership style would be more appropriate, as such leaders tend to work without collaboration or feedback from others and tend to be more independent in their decision making, which all seem to be acceptable in such culture.

\section{References}

Abrahamson, E., \& Hambrick, D. C. (1997). Attentional homogeneity in industries: The effect of discretion. Journal of Organizational Behavior, $\quad 18, \quad 513-532$. http://dx.doi.org/10.1002/(SICI)1099-1379(199711)18:1+<513:AID-JOB905>3.0.CO;2-8.

Ailon, G. (2008). Mirror, mirror on the wall: Culture's consequences in a value test of its own design. Academy of Management Review, 33(4), 885-904. https://doi.org/10.5465/AMR.2008.34421995 
Aktas, M., Gelfand, M. J., Hanges, P. J. (2016). Cultural tightness-looseness and perceptions of effective leadership. Journal of Cross-Cultural Psychology, 47(2), 294-309. https://doi.org/10.1177/0022022115606802

$\mathrm{Au}, \mathrm{K}$. Y. (1997). Another consequence of culture-intra-cultural variation. International Journal of Human Resource Management, 8, 743-755. https://doi.org/10.1080/095851997341496

$\mathrm{Au}, \mathrm{K}$. Y. (1999). Intra-cultural Variation: Evidence and Implications for International Business. Journal of International Business Studies, 30(4), 799-812. https://doi.org/10.1057/palgrave.jibs.8490840

$\mathrm{Au}, \mathrm{K}$. Y. (2000). Intra-cultural variation as another construct of international management: A study based on secondary data of 42 countries. Journal of International Management, 6, 217-238. https://doi.org/10.1016/S1075-4253(00)00026-0

Au, K. Y., \& Cheung, W. L. (2004). Intra-cultural Variation and Job Autonomy in 42 Countries. Organization Studies, 25(8), 1339-1362. https://doi.org/10.1177/0170840604046345

Berry, J. W. 1966. Temne and Eskimo perceptual skills. International Journal of Psychology, 1: 207-229. https://doi.org/10.1080/00207596608247156

Beugelsdijk, S., Slangen, A., Maseland, R., \& Onrust, M. (2014). The impact of home-host cultural distance on foreign affiliates sales: The moderating role of cultural variation within host countries. Journal of Business Research, 67, 1638-1646. https://doi.org/10.1016/j.jbusres.2013.09.004

Boldt, E. D. (1978b). Structural tightness, autonomy and observability: An analysis of Hutterite conformity and orderliness. Canadian Journal of Sociology, 3, 349-363. https://doi.org/10.2307/3340310

Boyd, B. K., \& Salamin, A. (2001). Strategic reward systems: A contingency model of pay system design. Strategic Management Journal, 22, 777-792. https://doi.org/10.1002/smj.170

Brewer, P., \& Venaik, S. (2014). The ecological fallacy in national culture research. Organization Studies, 35(7), 1063-1086. https://doi.org/10.1177/0170840613517602

Bridoux, F., \& Stoelhorst, J. W. (2014). Microfoundations for stakeholder theory: Managing stakeholders with heterogonous motives. Strategic Management Journal, 35(1), 107-125. https://doi.org/10.1002/smj.2089

Broderick, A. J., Greenley, G. E., \& Mueller, R. D. (2007). The behavioral homogeneity evaluation framework: Multi-level evaluations of consumer involvement in international segmentation. Journal of International Business Studies, 38(5), 746-763. https://doi.org/10.1057/palgrave.jibs.8400296

Buchholtz, A. K., Amason, A. C., and Rutherford, M. A. 1999. Beyond resources: The mediating effect of top management discretion and values on corporate philanthropy. Business and Society, 38: 167-187. https://doi.org/10.1177/000765039903800203

Campbell, J. L. (2007). Why would corporations behave in socially responsible ways? An institutional theory of corporate social responsibility. Academy of Management Review, 32, 946-967. https://doi.org/10.5465/AMR.2007.25275684

Carpenter, M. A., \& Golden, B. R. (1997). Perceived managerial discretion: A study of cause and effect. Strategic Management Journal, 187-206. https://doi.org/10.1002/(SICI)1097-0266(199703)18:3<187::AID-SMJ861>3.0.CO;2-U

Carpenter, S. (2000). Effects of cultural tightness and collectivism on self-concept and causal attributions. Cross-Cultural Research, 34, 38-56. https://doi.org/10.1177/106939710003400103

Chan, D. K., Gelfand, M. L., Triandis, H. C., \& Tzeng, O. (1996). Tightness and looseness revisited: some preliminary analyses in Japan and United States. International Journal of Psychology, 31(1), 1-12. https://doi.org/10.1080/002075996401179

Cho, T., \& Hambrick, D. (2006). Attention as the mediator between top management team characteristics and strategic change: The case of airline deregulation. Organization Science, 17, 453-460. https://doi.org/10.1287/orsc.1060.0192

Chua, R. Y. J., Roth, Y., \& Lemoine, J. F. (2015). The impact of culture on creativity: How cultural tightness and cultural distance affect global innovation crowdsourcing work. Administrative Science Quarterly, 60, 189-227. https://doi.org/10.1177/0001839214563595

Cohen, W. M., \& Levinthal, D. A. (1990). Absorptive capacity: A new perspective on learning and innovation. Administrative Science Quarterly, 35(1), 128-152. https://doi.org/10.2307/2393553 
Crossland, C., \& Hambrick, D. C. (2011). Differences in managerial discretion across countries: How nation-level institutions affect the degree to which CEOs matter. Strategic Management Journal, 32, 797-819. https://doi.org/10.1002/smj.913

Delmas, M., \& Toffel, M. W. (2004). Stakeholders and environmental management practices: An institutional framework. Business Strategy and the Environment, 13(4), 209-222. https://doi.org/10.1002/bse.409

Dheer, R. J. S., Lenartowicz, T., \& Peterson, M. F. (2015). Mapping India's Regional Subcultures: Implications for International Management. Journal of International Business Studies, 46(4), 443-467. https://doi.org/10.1057/jibs.2014.70

DiMaggio P., \& Powell, W. (1983). The iron cage revisited: institutional isomorphism and collective rationality in organizational fields. American Sociological Review, 48, 147-160. https://doi.org/10.2307/2095101

Dollinger, M. J., Golden, P. A., \& Saxton, T. (1997). The effect of reputation on the decision to joint venture. $\begin{array}{lllll}\text { Strategic } \quad \text { Management } & \text { Journal, } & 18, & \text { 127-140. }\end{array}$ http://dx.doi.org/10.1002/(SICI)1097-0266(199702)18:2<127:AID-SMJ859>3.0.CO;2-H

Donaldson, T., \& Preston, L. E. (1995). The stakeholder theory of the corporation: Concepts, evidence, and implications. Academy of Management Review, 20, 65-9. https://doi.org/10.5465/AMR.1995.9503271992

Engelmann, D., \& Strobel, M. (2004). Inequality aversion, efficiency, and maximum preferences in simple distribution experiments. American Economic Review, 94, 765-781. https://doi.org/10.1257/0002828042002741

Eun, C., Wang, L., \& Xiao, S. (2015). Culture and R2. Journal of Financial Economics, 115, 283-303. https://doi.org/10.1016/j.jfineco.2014.09.003

Fehr, E., \& Flak, A. (2002). Psychological foundations of incentives. European Economic Review, 46, 687-724. https://doi.org/10.1016/S0014-2921(01)00208-2

Finkelstein, S. (2009). Why is industry related to CEO compensation? A managerial discretion explanation. Open Ethics Journal, 3, 42-56. https://doi.org/10.2174/1874761200903020042

Fischer, R. (2006). Congruence and Functions of Personal and Cultural Values: Do My Values Reflect My Culture's Values? Personality and Social Psychology Bulletin, 32, 1419-1431. https://doi.org/10.1177/0146167206291425

Fischer, R., \& Schwartz, S. H. (2011). Whence differences in value priorities? Individual, cultural, or artefactual sources. Journal of Cross-Cultural Psychology, 42, 1127-1144. https://doi.org/10.1177/0022022110381429

Gardberg, N. A., \& Fombrun, C. J. (2006). Corporate citizenship: Creating intangible assets across institutional environments. Academy of Management Review, 31(2), 329-346. https://doi.org/10.5465/AMR.2006.20208684

Geletkanycz, M. A., \& Hambrick, D. C. (1997). The external ties of top executives: Implications for strategic choice and performance. Administrative Science Quarterly, 42, 654-681. https://doi.org/10.2307/2393653

Gelfand, M. J., LaFree, G., Fahey, S., \& Feinberg, E. (2013). Culture and extremism. Journal of Social Issues, 69, 495-517. https://doi.org/10.1111/josi.12026

Gelfand, M. J., Nishii, L. H., \& Raver, J. L. (2006). On the nature and importance of cultural tightness-looseness. Journal of Applied Psychology, 91, 1225-1244. https://doi.org/10.1037/0021-9010.91.6.1225

Gelfand, M.J., Raver, J.L., Nishii, L., Leslie, L.M., Lun, J., Lim, B.L. et al. (2011). Differences between tight and loose cultures: A 33-nation study. Science, 332, 1100-1104. https://doi.org/10.1126/science.1197754

Gunia, B. C. C., Brett, J. M., Nandkeolyar, A. K., \& Kamdar, D. (2011). Paying a price: Culture, trust, and negotiation consequences. Journal of Applied Psychology, 96, 774-789. https://doi.org/10.1037/a0021986

Gurven, M., Zanolini, A., \& Schniter, E. (2008). Culture sometimes matters: intra-cultural variation in pro-social behavior among Tsimane Amerindians. Journal of Economic Behavior \& Organization, 67(3), 587-607. https://doi.org/10.1016/j.jebo.2007.09.005

Hambrick, D. C. \& Mason, A. P. (1984). Upper Echelons: The organization as a Reflection of its top Managers. Academy of Management Review, 9(2), 193-206. https://doi.org/10.5465/AMR.1984.4277628

Hambrick, D. C., \& Abrahamson, E. (1995). Assessing managerial discretion across industries: A multi-method approach. Academy of Management Journal, 38, 1427-1441. https://doi.org/10.2307/256864

Hambrick, D. C., \& Finkelstein, S. (1987). Managerial discretion: A bridge between polar views of organizational 
outcomes. Research in Organizational Behavior, 9, 369-406.

Hanges, P. J., \& Dickson, M. W. (2006). Agitation over aggregation: Clarifying the development of and the nature of the GLOBE scales. Leadership Quarterly, 17(5), 522-536. https://doi.org/10.1016/j.leaqua.2006.06.004

Hannan, M. T., \& Freeman, J. (1977). The population ecology of organizations. American Journal of Sociology, 82, 929-964. https://doi.org/10.1086/226424

Harrison, J. S., Bosse, D. A., \& Phillips, R. A. (2010). Managing for stakeholders, stakeholder utility functions and competitive advantage. Strategic Management Journal, 31, 58-74. https://doi.org/10.1002/smj.801

Hofstede G. (1980). Culture's Consequences: International Differences in Work-Related Values. Sage: Thousand Oaks, CA.

Hofstede, G. (1991). Culture's and organizations: Software of the mind. London: McGraw Hill.

Hofstede, G. (2001). Culture's Consequences: Comparing values, behaviors, institutions, and organizations across nations (2nd ed.). Thousand Oaks, CA: Sage.

Hoorn, A. (2015). Differences in work values: understanding the role of intra- versus inter-country variation. The International Journal of Human Resource Management, 26(7), 1002-1020. https://doi.org/10.1080/09585192.2013.872165

House, R., Hanges, P., Javidan, M., Dorfman, P., Gupta, V. (Eds..). (2004). Culture, Leadership, and Organizations: The GLOBE Study of 62 Societies. Sage: Thousand Oaks, CA.

House, R. J., Dorfman, P. W., Javidan, M., Hanges, P. J., \& de Luque, M. F. (2014). Strategic Leadership Across Cultures: The GLOBE Study of CEO Leadership Behavior and Effectiveness in 24 Countries. Thousand Oaks, California: Sage Publications Inc. https://doi.org/10.4135/9781506374581

Key, S. (2002). Perceived managerial discretion: An analysis of individual ethical intentions. Journal of Managerial Issues, 14, 218-233. http://www.jstor.org/stable/40604385

Kim, E. H. (2013). Deregulation and differentiation: Incumbent investment in green technologies. Strategic Management Journal, 34, 1162-1185. https://doi.org/10.1002/smj.2067

Kirkman, B. L., Chen, G., Farh, J., Chen, Z. X., \& Lowe, K. B. (2009). Individual power distance orientation and follower reactions to transformational leaders: A cross-level, cross-cultural examination. Academy of Management Journal, 52(4), 744-764. https://doi.org/10.5465/AMJ.2009.43669971

Klein, J. K, Kozlowski, S. W. (2000). From micro to meso: critical steps in conceptualizing and conducting multilevel research. Organizational Research Methods, 3, 211-236. https://doi.org/10.1177/109442810033001

Lenartowicz, T., \& Roth, K. (2001). Does subculture within a country matter? A cross-culture study of motivational domains and business performance in Brazil. Journal of International Business Studies, 32(2), 305-325. https://doi.org/10.1057/palgrave.jibs.8490954

Leung, K., Bhagat, R., Buchan, N., Erez, M., \& Gibson, C. (2005). Culture and international business: Recent advances and their implications for future research. Journal of International Business Studies, 36(4), 357-378. https://doi.org/10.1057/palgrave.jibs.8400150

McClelland, P. L., Liang, X., \& Barker, V. L. (2010). CEO commitment to the status quo: Replication and extension using content analysis. Journal of Management, 36, 1251-1277. https://doi.org/10.1177/0149206309345019

Mitchell, R. K., Agle, B. R., \& Wood, D. J. (1997). Toward a theory of stakeholder identification and salience: Defining the principle of who and what really counts. Academy of Management Review, 22, 853-886. https://doi.org/10.5465/AMR.1997.9711022105

Mullen, M. R. (1995). Diagnosing measurement equivalence in cross-national research. Journal of International Business Studies, 26, 573-596. https://doi.org/10.1057/palgrave.jibs.8490187

Nadkarni, S., \& Barr, P. S. (2008). Environmental context, managerial cognition, and strategic action: An integrated view. Strategic Management Journal, 29(13), 1395-1427. https://doi.org/10.1002/smj.717

Nelson, R. R. (1991). Why do firms differ, and how does it matter? Strategic Management Journal, 12, 61-74. https://doi.org/10.1002/smj.4250121006

Pelto, P. J. (1968). The difference between 'tight' and 'loose' societies. Transaction, 5, 37-40. https://doi.org/10.1007/bf03180447 
Pelto, P. J., \& Pelto, G. H. (1975). Intra-cultural Diversity: Some Theoretical Issues. American Ethnologist, 2, 1-18. https://doi.org/10.1525/ae.1975.2.1.02a00010

Peltokorpi, V., \& Froese, F. (2014). Expatriate personality and cultural fit: The moderating role of host country context on job satisfaction. International Business Review, 23, 293-302. https://doi.org/10.1016/j.ibusrev.2013.05.004

Peteraf, M., \& Reed, R. (2007). Managerial discretion and internal alignment under regulatory constraints and change. Strategic Management Journal, 28, 1089-1112. https://doi.org/10.1002/smj.628

Peterson, M. F., Arregle, J. L., \& Martin, X. (2012). Multilevel models in international business research. Journal of International Business Studies, 43(5), 451-457. https://doi.org/10.1057/jibs.2011.59

Phillips, R. A., Berman, S. L., Elms, H., \& Johnson-Cramer, M. E. (2011). Stakeholder orientation, managerial discretion and nexus rents. In Stakeholder Theory: Impact and Prospects, edited by Robert A. Phillips, 163-192. Cheltenham, UK: Edward Elgar. https://doi.org/10.4337/9780857936349.00013

Phillips, R. A., Berman, S. L., Elms, H., \& Johnson-Cramer, M. E. (2010). Strategy, stakeholders and managerial discretion. Strategic Organization, 8(2), 176-183. https://doi.org/10.1177/1476127010365721

Puia, G., \& Ofori-Dankwa, J. (2013). The effects of national culture and ethno-linguistic diversity on innovativeness. Baltic Journal of Management, 8(3), 349-371. https://doi.org/10.1108/BJOM-Jan-2012-0002

Quigley, T. J., \& Hambrick, D. C. (2012). When the former CEO stays on as board chair: Effects on successor discretion, strategic change, and performance. Strategic Management Journal, 33, 834-859. https://doi.org/10.1002/smj.1945

Ralston, D. A., Egri, C. P., Furrer, O., Kuo, M., Li, Y., et al. (2014). Societal-level versus individual-level predictions of ethical behavior: A 48-Society study of collectivism and individualism. Journal of Business Ethics, 122(2), 283-306. https://doi.org/10.1007/s10551-013-1744-9

Riasi, A., \& Asadzadeh, N. (2016). How coercive and legitimate power relate to different conflict management styles: a case study of Birjand high schools. Journal of Studies in Education, 6(1), 147-159. https://doi.org/10.5296/jse.v6i1.8946

Richter, N. F., Hauff, S., Schlaegel, C., Gudergan, S., Ringle, C. M., \& Gunkel, M. (2016). Using cultural archetypes in cross-cultural management studies. Journal of International Management, 22, 63-83. https://doi.org/10.1016/j.intman.2015.09.001

Robinson, W. S. (1950). Ecological correlations and behavior of individuals. Journal of the American Statistical Association, 15(3), 517-536. https://doi.org/10.2307/2087176

Ronen, S., \& Shenkar, O. (2013). Mapping world cultures: Cluster formation, sources and implications. Journal of International Business Studies, 44(9), 867-897. https://doi.org/10.1057/jibs.2013.42

Roth, K. (1992). Implementing international strategy at the business unit level: The role of managerial $\begin{array}{llllll}\text { decision-making characteristics. Journal of } & \text { Management, } & \text { 18, } & \text { 769-789. }\end{array}$ https://doi.org/10.1177/014920639201800410

Roth, K., Kostova, T., \& Dakhli, M. (2011). Exploring cultural misfit: Causes and consequences. International Business Review, 20, 15-26. https://doi.org/10.1016/j.ibusrev.2010.06.005

Schwartz, S. H. (1999). A theory of cultural values and some implications for work. Applied Psychology: An International Review, 48(1), 23-47. https://doi.org/10.1111/j.1464-0597.1999.tb00047.x

Schwartz, S. H., \& Sagie, G. (2000). Value Consensus and Importance: A Cross-National Study. Journal of Cross-Cultural Psychology, 31, 465-497. https://doi.org/10.1177/0022022100031004003

Steel, P., \& Taras, V. (2010). Culture as a consequence: A multilevel multivariate meta-analysis of the effects of individual and country characteristics on work-related cultural values. Journal of International Management, 16(3), 211-233. https://doi.org/10.1016/j.intman.2010.06.002

Surroca, J., Prior, D., \& Tribo Gine, J. A. (2016). Using panel data dea to measure CEOs' focus of attention: An application to the study of cognitive group membership and performance. Strategic Management Journal, 37(2), 370-388. https://doi.org/10.1002/smj.2350 
Taras, V., Steel, P., \& Kirkman, B. L. (2010). Negative practice-value correlations in the GLOBE data: Unexpected findings, questionnaire limitations and research directions. Journal of International Business Studies, 41, 1330-1338. https://doi.org/10.1057/jibs.2010.30

Ter Hofstede, F., Wedel, M., \& Steenkamp, J. E. (2002). Identifying spatial segments in international markets. Marketing Science, 21(2), 160-177. https://doi.org/10.1287/mksc.21.2.160.154

Tsui, A. S., Nifadkar, S. S., \& Ou, A. Y. (2007). Cross-National, Cross-Cultural Organizational Behavior Research: Advances, Gaps, and Recommendations. Journal of Management, 33, 426-478. https://doi.org/10.1177/0149206307300818

Tung, R. L. (2008). The cross-cultural research imperative: The need to balance cross-national and intra-national diversity. Journal of International Business Studies, 39, 41-46. https://doi.org/10.1057/palgrave.jibs.8400331

Tung, R. L., \& Baumann, C. (2009). Comparing the attitudes toward money, material possessions and savings of overseas Chinese vis-à-vis Chinese in China: Convergence, Divergence or Crossvergence, vis-à-vis "One size fits all" Human Resource Management policies and practices. The International Journal of Human Resource Management, 20, 2382-2401. https://doi.org/10.1080/09585190903239724

Tung, R. L., \& Verbeke, A. (2010). Beyond Hofstede and GLOBE: Improving the quality of cross-cultural research. Journal of International Business Studies, 41, 1259-1274. https://doi.org/10.1057/jibs.2010.41

Uhl-Bien, M., \& Carsten, M. (2007). Being ethical when the boss is not. Organizational Dynamics, 36(2), 187-201. https://doi.org/10.1016/j.orgdyn.2007.03.006

Uz, I. (2015). The Index of Cultural Tightness and Looseness Among 68 Countries. Journal of Cross-Cultural Psychology, 46, 319-335. https://doi.org/10.1177/0022022114563611

Venaik, S., \& Brewer, P. (2010). Avoiding uncertainty in Hofstede and GLOBE. Journal of International Business Studies, 41, 1294-1315. https://doi.org/10.1057/jibs.2009.96

Venaik, S., \& Midgley, D. F. (2015). Mindscapes across landscapes: Archetypes of transnational and subnational culture. Journal of International Business Studies, 46, 1051-1079. https://doi.org/10.1057/jibs.2015.11

Wangrow, B. D., Schepker, J. D., Barker III, L. V. (2015). Managerial Discretion: An Empirical Review and Focus on Future Research Directions. Journal of Management, 41, 99-135. https://doi.org/10.1177/0149206314554214

Wedel, M., Ter Hofstede, F., \& Steenkamp, J. E. M. (1998). Mixture model analysis of complex samples. Journal of Classification, 15(2), 225-244. https://doi.org/10.1007/s003579900032

Wolfe, R. A., \& Putler, D. S. (2002). How tight are the ties that bind stakeholder groups? Organization Science, 14, 54-80. https://doi.org/10.1287/orsc.13.1.64.544 